\title{
Erratum: Salmonella blood stream infections in a tertiary care setting in Ghana
}

Appiah-Korang Labi ${ }^{1}$, Noah Obeng-Nkrumah ${ }^{2 *}$, Naa Addison ${ }^{1}$ and Eric S. Donkor ${ }^{2}$

Following publication of [1] it has come to our attention that there was an error in the last author's name which should be Eric S. Donkor and not Eric Sampene-Donkor.

We would like to sincerely apologize for the error and any inconvenience caused.

\footnotetext{
Author details

${ }^{1}$ Department of Microbiology, Korle-Bu Teaching Hospital, Accra, West Africa, Ghana. ${ }^{2}$ Microbiology Department, University of Ghana Medical School, Accra, West Africa, Ghana.
}

Received: 26 March 2015 Accepted: 26 March 2015

Published online: 10 July 2015

\section{Reference}

1. Labi KA, Obeng-Nkrumah N, Addison N, Sampene-Donkor E. Salmonella blood stream infections in a tertiary care setting in Ghana. BMC Infectious Diseases. 2014;14:3857

\footnotetext{
* Correspondence: successfulnoahforchrist@yahoo.com

${ }^{2}$ Microbiology Department, University of Ghana Medical School, Accra, West Africa, Ghana

Full list of author information is available at the end of the article
}

Submit your next manuscript to BioMed Central and take full advantage of:

- Convenient online submission

- Thorough peer review

- No space constraints or color figure charges

- Immediate publication on acceptance

- Inclusion in PubMed, CAS, Scopus and Google Scholar

- Research which is freely available for redistribution

Submit your manuscript at www.biomedcentral.com/submit 